Noticias

vírus mortos ou com partes dos vírus, a fim de evitar a replicação viral nas pessoas vacinadas: a formulação atual inclui vírus atenuados responsáveis pela maioria das reações adversas. Uma outra linha de investigação na Fiocruz consiste na liberação de mosquitos Aedes aegypti contaminados com a bactéria Wolbachia nos quais os vírus não conseguem atravessar a parede do intestino e seguir até as glândulas salivares. "Com isso, é possível conviver com os mosquitos sem que eles transmitam a febre amarela e outras arboviroses como a zika, chicungunha e dengue", explica Tauil.

Como no Brasil, no ciclo urbano da doença, o Aedes é o único transmissor, a febre amarela fica restrita à forma silvestre, transmitida por mosquitos de copas de árvores do gênero Sabethes e Haemogogus. Em projeto piloto em bairros das cidades do Rio de Janeiro e Niterói, houve substituição de até $80 \%$ da população de mosquito sem a bactéria por insetos com a Wolbachia. 0 próximo passo é estudar o impacto epidemiológico, isto é, se haverá redução da incidência de arboviroses. Atualmente, o tratamento dos pacientes acometidos pela febre amarela é apenas sintomático, no entanto, remédios mais específicos estão sendo pesquisados. De acordo com André Siqueira, infectologista do Instituto Nacional de Infectologia Evandro Chagas, há estudos com antivirais ou para desenvolver medicamentos que modulam a resposta inflamatória. "No entanto, apesar de mostrarem ação em modelos experimentais, não foram feitos estudos em pessoas infectadas", diz. Além das pesquisas com novos medicamentos, 0 infectologista acredita que seja necessário o desenvolvimento de testes sorológicos mais eficientes: “Os testes rápidos, que dispensem técnicas laboratoriais trabalhosas, apresentam grandes vantagens para o manejo adequado dos casos".

DEVER DE CASA As inovações e novos conhecimentos certamente ajudarão no enfrentamento da doença no futuro próximo. Porém, Pedro Tauil destaca: “É uma doença evitável por meio de um instrumento muito eficaz e bastante seguro, a vacina. Ela deve ser aplicada não só nas épocas de crise, mas deve estar na rotina vacinal de toda população exposta ao risco de adquirir a doença, das pessoas que vivem ou se deslocam para as áreas rurais onde há circulação do vírus entre macacos e alguns outros animais", finaliza.

Roberto Takata

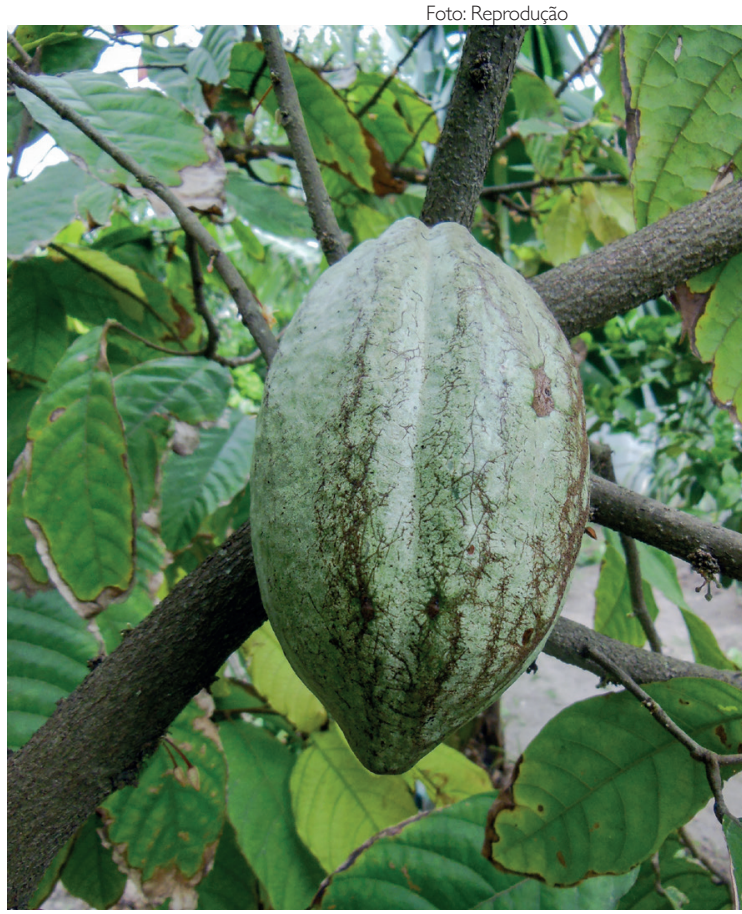

Cacau já foi um dos principais produtos da cesta de exportação brasileira

CACAU NO BRASIL

\section{Uma oportunidade que (ainda) não se concretizou}

De um dos maiores produtores e exportadores de cacau do mundo, hoje o país ocupa o quinto lugar, tendo que importar o fruto para suprir a produção nacional de chocolate. No entanto, nos últimos anos, pesquisas para melhoramento das sementes sinalizam para a recuperação da produção nacional. 
brasileiros. Dados da Confederação da Agricultura e Pecuária do Brasil (CNA) apontam que 66 mil propriedades rurais no país se dedicam à produção de cacau, 33 mil delas no sul da Bahia, maior estado produtor, seguido do Pará. Novas técnicas de plantio e melhoramento das sementes possibilitam produzir um cacau de melhor qualidade, tecnologias acessíveis inclusive para os pequenos agricultores. Outra mudança é a tentativa de agregar valor ao cacau, na região de Ilhéus, por exemplo, já existem fábricas de chocolate dentro das fazendas. No Centro de Desenvolvimento e Capacitação Tecnológica Euclides Teixeira Neto, da Ceplac (BA), foi instalada uma fábrica de achocolatado que atua em regime de cooperativa e o produto é vendido para a merenda escolar de municípios da Bahia. O cultivo de cacau orgânico, sem agrotóxicos e em sistema de cabruca, também tem contribuído para valorizar a produção, principalmente de pequenos produtores. Nesse sistema, o cacau é plantado sombreado por árvores da Mata Atlântica, o que garante umidade e matéria orgânica para a planta.

Em outra ponta, pesquisas desenvolvidas em parceria com instituiçôes fora do eixo de produção de cacau estão permitindo compreender o comportamento da planta fora do seu centro de origem. Neste sentido, destaca-se a pesquisa inovadora sobre a estrutura genética e a diversi-

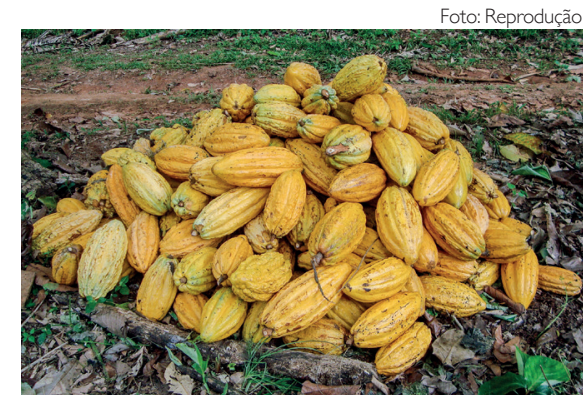

Nos últimos anos a produção de cacau na Bahia voltou a crescer

dade molecular do chamado "cacau da Bahia”. Este termo se aplica a um conjunto de variedades locais desenvolvidas nos últimos dois séculos e que envolve as variedades Amelonado, trazida do Pará no século XVIII, Maranhão, introduzida em 1874, e Pará, introduzida em 1876, bem como suas mutações espontâneas. O estudo, que envolveu pesquisadores da Universidade Estadual do Sudoeste da Bahia (Uesb), Universidade Estadual Paulista (Unesp), Universidade Estadual de Santa Cruz (Uesc), Instituto Federal de Educação, Ciência e Tecnologia Baiano (IF Baiano), Universidade Estadual de Campinas (Unicamp) e da Ceplac, buscava encontrar a razão da baixa resistência do cacau da Bahia à vassoura-de-bruxa para torná-lo mais resistente ao fungo.

Descobriu-se que a base genética do cacau da Bahia é muito estreita; praticamente todos os cacaueiros baianos têm a sua origem em sementes da variedade Amelonado, trazida por Warneaux há mais de
270 anos. Essa baixa diversidade genética permitiu obter frutos de alta qualidade, mas conferiu fragilidade aos cacaueiros do sul da Bahia, por ausência de variedades que pudessem resistir a uma doença, no caso a vassoura-de-bruxa. $\mathrm{O}$ estudo ainda permitiu constatar que os híbridos desenvolvidos nos anos 1950 e 1960 (e cultivados até hoje), em vez de aumentarem a variação genética na população cacaueira, acabaram por reduzi-la ainda mais, já que também foram produzidos com base apenas na qualidade do cacau.

Mas as perspectivas são muito boas. Esse estudo aprofundado envolveu a análise de folhas de 279 cacaueiros de sete fazendas e duas instituiçôes de pesquisa (o IF Baiano e a Ceplac), localizados em seis municípios do sul da Bahia (Gandu, Igrapiúna, Uruçuca, Ilhéus, Camacan e Canavieiras). Graças a isso foi possível identificar também árvores resistentes à doença e com maior variação genética que aquela encontrada nos híbridos atualmente existentes. Isso propiciará o desenvolvimento de programas de melhoramento genético de cacau que permitam obter plantas resistentes à vassoura-de-bruxa e a outras doenças, bem como a obtenção de plantas mais resistentes às secas que por vezes também afetam os cacaueiros baianos. 